\title{
FUNGSI TINDAK TUTUR DIREKTIF PERAWAT TERHADAP PASIEN DI RUANG FISIOTERAPI RSU HAJI MEDAN-SUMATRA UTARA
}

\author{
Speech Act Directive Functions of Nurses to the Patients in the \\ Physiotherapy Room at RSU Haji Medan-Sumatra Utara
}

\author{
Arni Chairul \\ Politeknik Kesehatan Kementrian Kesehatan Medan Jurusan Keperawatan \\ Jalan Bunga Ncole Medan Tuntungan-Sumatra Utara \\ e-mail: arnichairul76@gmail.com \\ Tanggal naskah masuk 26 April 2018 \\ Tanggal akhir penyuntingan 6 Juni 2018
}

\begin{abstract}
In communicating activities certainly can not be separated from the theory of speech acts. Speech acts as a form of communication event is not an event that happens by itself, but has a function, contains a specific purpose can cause influence or effect on the said partner. The speech acts is a theory that tries to study the meaning of language based on the relationship of speech with the actions performed by the speaker.Language is used by speakers to convey specific intentions to speech partners such as ordering, begging, asking, and etc.Such speech acts as speech acts are grouped into speech acts directive. Speech from a (speaker) is of course not merely the origin of speech, but it contains certain intentions. The classification of speech acting speech function are : competitive,convivial, collaborative, conflictive. The purpose of this study was to identify the function of speech acts of the nurse directive to the patient in the physiotherapy room at RSU. Haji Medan - North Sumatera.This research is a qualitative research using descriptive and comparative method. From the data analysis found the function of speech act directive, competitive 'compete' with its subfunctions to govern and ask; and collaborative functions 'in collaboration' with its subfunctions stating, teaching, reporting and announcing. From the discussion it is suggested that nurses use speech act directive that has indicators of politeness in Indonesian language so that the function of acting speech directive can be achieved in conveying the intent and purpose to the patient.

Keywords: function of speech act directive, competitive, convivial, collaborative, conflictive, nurse, patient.
\end{abstract}

Abstrak

Dalam kegiatan berkomunikasi tentu tidak dapat terlepas dari adanya teori tindak tutur. Tindak tutur sebagai wujud peristiwa komunikasi bukanlah peristiwa yang terjadi dengan sendirinya, melainkan mempunyai fungsi, mengandung maksud dan tujuan tertentu serta dapat menimbulkan pengaruh atau akibat pada mitra tutur. Tindak tutur adalah teori yang mencoba mengkaji makna bahasa yang didasarkan pada hubungan tuturan dengan tindakan yang dilakukan oleh penuturnya. Bahasa digunakan oleh penutur untuk menyampaikan maksud-maksud tertentu kepada mitra tutur seperti menyuruh, memohon, meminta, dan sebagainya. Tindak tutur seperti ini merupakan tindak tutur yang dikelompokkan ke dalam tindak tutur direktif. Tuturan dari 
seorang (penutur) tentu saja tidak semata-mata hanya asal bicara, tetapi mengandung maksud tertentu. Adapun klasifikasi fungsi tindak tutur direktif dibagi dalam 4 (empat) fungsi,yakni : kompetitif (competitive), menyenangkan (convivial), bekerja sama (collaborative), bertentangan (conflictive). Tujuan penelitian ini adalah untuk mengidentifikasi fungsi tindak tutur direktif perawat terhadap pasien di ruang fisioterapi RSU. Haji Medan - Sumatera Utara. Penelitian ini adalah penelitian kualitatif dengan menggunakan metode deskriptif dan komparatif. Dari analisis data ditemukan fungsi tindak tutur direktif, kompetitif 'bersaing' dengan subfungsinya memerintah dan meminta; dan fungsi collaborative 'bekerjasama' dengan subfungsinya menyatakan, mengajarkan, melapor dan mengumumkan. Dari pembahasan disarankan agar perawat menggunakan tindak tutur direktif yang memiliki indikator kesantunan berbahasa Indonesia sehingga fungsi dari tindak tutur direktif tersebut dapat tercapai dalam menyampaikan maksud dan tujuan kepada pasien.

Kata kunci: fungsi tindak tutur direktif, kompetitif, menyenangkan, bekerja sama, bertentangan, perawat, pasien.

\section{PENDAHULUAN}

Dalam lingkungan rumah sakit dibutuhkan proses interaksi yang baik antara perawat dan pasien, perawat dan profesional kesehatan lain, serta perawat dan komunitas, yang terjadi melalui komunikasi, baik dalam bentuk verbal dan nonverbal, tertulis dan tidak tertulis, atau pun terencana dan tidak terencana. Agar perawat efektif dalam berinteraksi, mereka harus memiliki keterampilan komunikasi yang baik. Oleh karena itu mereka harus menyadari katakata dan bahasa tubuh yang mereka sampaikan pada orang lain. Menurut Kathleen dalam Hermawan (2009) menyatakan bahwa ketika perawat mengemban peran kepemimpinan, mereka harus menjadi efektif, baik dalam keterampilan komunikasi verbal maupun komunikasi tertulis (hlm. 02).

Perawat merupakan orang yang pertama yang berhadapan langsung dengan pasien. Tuturan atau bahasa yang digunakan perawat adalah salah satu unsur penentu kesembuhan pasien dan kepuasan pelayanan. Keberadaan perawat dan dokter merupakan ujung tombak pelayanan kesehatan, hal ini harus benar-benar diperhatikan dan dikelola secara profesional sehingga mampu meningkatkan mutu pelayanan keperawatan dan pengobatan, Ester (dalam Wahyuningsih \& Subekti, 2005).
Sehingga pada akhirnya perawat merupakan orang yang benar-benar dituntut menggunakan bahasa yang santun karena mau tidak mau setiap hari akan berhubungan dengan pasien yang mempunyai latar belakang budaya yang berbeda-beda, baik dari segi pendidikan, usia, dan pekerjaan.

Berdasarkan data penelitian sebelumnya yang penulis teliti dengan judul "Analisis Tindak Tutur Direktif Perawat terhadap Pasien di Ruang Fisioterapi RSU. Haji Medan - Sumatra Utara" (2015), menyatakan bahwa ada 6 bentuk tindak tutur direktif dari teori Jhon Rogers Searle yang digunakan oleh Perawat Pertama yang bertugas di ruang fisioterapi RSU Haji Medan SumatraUtara, yakni : Tindak Tutur Direktif Permintaan (Requestif) sebesar 5,8\%, Tindak Tutur Direktif Pertanyaan (Questions) sebesar 68,1\%, Tindak Tutur Direktif Pelarangan (Prohibitives) sebesar 1,5\%, Tindak Tutur Direktif Persyaratan (Requirement) sebesar 13\%, Tindak Tutur Direktif Persetujuan (Permistives) sebesar 1,5\%, dan Tindak Tutur Direktif Nasihat (Advisories) sebesar $10,1 \%$. Oleh karena itu penulis tertarik melanjutkan masalah ini untuk dijadikan bahan penelitian berikutnya dengan judul: "Fungsi Tindak Tutur Direktif Perawat Terhadap Pasien di Ruang Fisioterapi RSU. Haji Medan - 
Sumatera Utara". Tujuan penelitian ini adalah untuk mengidentifikasi fungsi tindak tutur direktif yang telah digunakan perawat terhadap pasien di ruang fisioterapi RSU Haji Medan - Sumatera Utara. Manfaat penelitian ini diharapkan memberikan kontribusi dan referensi terhadap pusat pelayanan kesehatan masyarakat khususnya perawat di rumah sakit agar menjadi bahan rujukan sehingga perawat dapat bertindak tutur direktif yang baik dan sopan dalam melakukan pelayanan terhadap pasien.

\section{LANDASAN TEORI}

\section{Teori Tindak Tutur Jhon Rogers Searle (1965)}

.Tindak tutur adalah teori yang mencoba mengkaji makna bahasa yang didasarkan pada hubungan tuturan dengan tindakan yang dilakukan oleh penuturnya Searle (dalam Rusminto, 2009: 74-75 : Anwari dkk, 2013 : 2). Sementara menurut Chaer dan Agustina (dalam HQ dkk, 2012 : 63), mendefinisikan tindak tutur sebagai gejala individual, bersifat psikologis dan keberlangsungannya ditentukan oleh kemampuan bahasa si penutur dalam menghadapi situasi tertentu. Bersamaan dengan hal ini menurut Leech (dalam Rosnilawati dkk, 2013 : 462), ia berpandangan bahwa tindak tutur adalah perangkat tuturan yang paling kecil dan merupakan bagian dari peristiwa tutur. Sedangkan menurut Chaer ( dalam Pratama dkk, 2013 : 03), ia mengatakan tindak tutur dan peristiwa tutur merupakan dua gejala yang terdapat pada satu proses, yakni proses komunikasi, di mana teori ini diperkuat oleh Searle yang berpendapat bahwa unsur yang paling kecil dalam komunikasi adalah tindak tutur.

Dari uraian di atas dapat dikatakan bahwa tindak tutur adalah gejala individu yang bersifat psikologis dan ditentukan oleh kemampuan bahasa penutur dalam menghadapi peristiwa tertentu, sehingga tindak tutur lebih menitik beratkan pada makna atau arti tindak (act) dalam suatu tuturan.

Selanjutnya teori tindak tutur Austin mendapat pengembangan lanjut dari J.R. Searle (dalam Leech 1981; Hasibuan, 2005 : 88-89), yang di antara pendapatnya memandang teori bahasa sebagai bagian dari teori tindak (action theory). Menurut Searle (1969), di dalam teori Austin ada hal yang membingungkan, antara verba dan tindakan, terlalu banyak tumpang tindih, dan terlalu banyak heterogenitas dalam kategori serta, yang paling penting, tidak adanya prinsip klasifikasi yang konsisten. Oleh karena itu Searle mengklasifikasikan tindak tutur menjadi (5) lima kelompok: representatif, direktif, komisif, ekspresif, dan deklarasi, Rustono (dalam Raharjo, 2012 : 206-207), yakni :

1) Tindak tutur Representatif, yang menunjukkan komitmen penutur terhadap kebenaran proposisi yang diucapkan (meliputi, antara lain: pemberian pernyataan, pembuatan kesimpulan).

2) Tindak tutur Direktif, yang menunjukkan upaya penutur mempengaruhi lawan bicara untuk melakukan sesuatu (meliputi, antara lain: meminta, bertanya).

3) Tindak tutur Komisif, yang menunjukkan komitmen penutur terhadap tindak yang akan dilakukan (meliputi, antara lain: berjanji, menakut-nakuti, menawarkan).

4) Tindak tutur Ekspresif, yang menunjukkan sikap psikologis (meliputi, antara lain: mengucapkan terima kasih, memuji, yang berarti bahwa dua hal terjadi secara mengucapkan selamat datang, mengucapkan selamat).

5) Tindak tutur Deklaratif, yang menunjukkan ucapan yang dapat digolongkan kepada tiga perubahan secara langsung tentang status sesuatu atas putusan lembagalembaga otorita non linguistis 
(meliputi, antara lain: memecat, menyatakan perang, menikahkan, dan membebastugaskan)

Hal ini senada yang diuraikan oleh AlHindawi, etc (2014:30-31), the classes of Searle's speech acts are: (Van Eemeren \& Grootendorst, 1983: p. 22). They are :

a) Representatives: Commit the speaker to the truth of the proposition expressed. In this class, the fit is between words and world. Examples are: asserting, concluding, complaining, etc.

b) Directives: Make the speaker intend to produce some effect through an action by the addressee. The fit is between world and words. Examples are: commanding, requesting, advising, etc.

c) Commisives: Commit the speaker to some future course of action, in which the fit becomes between world and words. Examples are: promising, offering, threatening, etc.

d) Expressives: As the name suggests, these are used to express the speaker's attitude towards a state of affairs which the speech act presupposes. In this class, no direction of fit exists. Examples are: thanking, apologizing, congratulating, etc.

e) Declarations: Require an extra linguistic institution which provides rules for their use. In this class, the fit is two-valued (wordsto-world and world-to-words). Examples are: christening, wedding, dismissing, etc.

Selanjutnya teori di atas diperjelas lagi oleh Searle (dalam Syahrul, 2008 : 32 ; HQ, 2012 : 63), di mana ia mengatakan bahwa suatu tindak tutur memiliki makna di dalam konteks dan makna dikategorikan ke dalam makna lokusi, ilokusi, dan perlokusi. Ketiga macam tindak tutur di dalam pemakaian bahasa yang sesungguhnya di masyarakat tersebut adalah tindak tutur lokusi (locutionary acts), tindak tutur ilokusi (illocutionary acts), dan tindak tutur perlokusi (perlocutionary acts).

1. Tindak tutur Lokusi adalah tindak tutur untuk menyatakan sesuatu. Tindak tutur lokusi ini disebut sebagai The Act of Saying Something (Wijana, 2009: 20). Tindak tutur lokusi merupakan suatu tindakan bertutur yang dapat berupa kata, frasa, ataupun kalimat sesuai dengan makna yang terkandung dalam kata, frasa, ataupun kalimat itu sendiri.

2. Tindak tutur Ilokusi adalah tindak tutur yang selain berfungsi untuk mengatakan sesuatu dan dapat juga dipergunakan untuk melakukan sesuatu. Tindak tutur ilokusi ini disebut sebagai The Act of Doing Something (Wijana, 2009: 22). Tindak tutur ini merupakan tindak tutur yang maksud penyampaiannya bergantung pada siapa, kapan, dan di mana tuturan tersebut dilakukan, sehingga tuturan ini tidak mudah diidentifikasi begitu saja seperti tindak tutur lokusi.

Menurut Searle (Rahardi, 2003: 72), tindak tutur ilokusi ini dapat digolongkan dalam aktivitas bertutur itu ke dalam 5 (lima) macam bentuk tuturan yang masing-masing memiliki fungsi komunikatifnya sendiri. Kelima macam bentuk tuturan tersebut adalah representatif/asertif, direktif, deklarasi, komisif, dan ekspresif.

(1) Tindak tutur Representatif, yang menunjukkan komitmen penutur terhadap kebenaran proposisi yang diucapkan (meliputi, antara lain: pemberian pernyataan, pembuatan kesimpulan). 
(2) Tindak tutur Direktif, yang menunjukkan upaya penutur mempengaruhi lawan bicara untuk melakukan sesuatu (meliputi, antara lain: meminta, bertanya).

(3) Tindak tutur Komisif, yang menunjukkan komitmen penutur terhadap tindak yang akan dilakukan (meliputi, antara lain: berjanji, menakut -nakuti, menawarkan).

(4) Tindak tutur Ekspresif, yang menunjukkan sikap psikologis (meliputi, antara lain : mengucapkan terima kasih, memuji, mengucapkan selamat datang, mengucapkan selamat).

(5) Tindak tutur Deklaratif, yang menunjukkan perubahan secara langsung tentang status sesuatu atas putusan lembaga-lembaga otorita non linguistis (meliputi, antara lain: memecat, menyatakan perang, menikahkan, dan membebastugaskan)

3. Tindak tutur Perlokusi adalah tindak tutur yang diutarakan oleh seseorang dan seringkali mempunyai daya pengaruh (perlocution force) atau efek bagi yang mendengarkannya. Efek atau daya pengaruh ini dapat secara sengaja maupun tidak sengaja dikreasikan oleh penuturnya. Tindak tutur ini disebut juga The Act of Affecting Someone (Wijana, 2009: 23).

Selaras dengan teori Searle (dalam Syahrul, 2008 dan HQ, dkk, 2012:63), ia menyatakan bahwa suatu tindak tutur memiliki makna di dalam konteks dan makna dikategorikan ke dalam makna lokusi, ilokusi, dan perlokusi. Hal ini ditegaskan juga oleh Searle (dalam Wijaya dan Rohmadi, 2011:21; Yuliana dkk, 2013 : 04), ia menyatakan bahwa dalam praktik penggunaan bahasa terdapat setidaknya (3) tiga macam tindak tutur. Ketiga macam tindak tutur adalah sebagai berikut : Pertama, tindak tutur lokusi, yaitu tindak bertutur dengan kata, frasa, dan kalimat sesuai dengan makna yang dikandung oleh kata, frasa, dan kalimat itu. Kedua, tindak tutur ilokusi, yaitu tindak tutur untuk melakukan sesuatu dengan maksud dan fungsi tertentu pula. Ketiga, tindak tutur perlokusi, yaitu tindak tutur yang menumbuhkan pengaruh (effect) kepada mitra tutur.

Dari uraian di atas dapat dikatakan bahwa ada (3) tiga jenis tindak tutur utama, yaitu tindak tutur lokusi, tindak tutur ilokusi maupun tindak tutur perlokusi, di mana tindak tutur lokusi adalah tindak tutur untuk menyatakan sesuatu, tindak tutur ilokusi adalah tindak tutur yang tidak hanya berfungsi untuk menginformasikan sesuatu namun juga untuk melakukan sesuatu, dan tindak perlokusi adalah tindak tutur untuk mempengaruhi lawan tutur, senada dengan Searle (dalam Wijana, 2009 ; Hapsari, 2014 : 02)

\section{Teori Tindak Tutur Direktif}

Dalam tindak tutur keberadaan seseorang diekspos dengan perilaku verbal dan nonverbal. Menurut Cangara dalam Firdaus dkk, (2012), ia menyatakan kode verbal dalam pemakaiannya menggunakan bahasa (hlm.145-147), sedangkan perilaku nonverbal seperti yang diungkapkan oleh Baraja (2008) adalah bahasa yang menggunakan ungkapan isyarat, gerakgerik atau mimik, yang mempunyai arti dan makna, sebagai pesan dari pikiran dan perasaan. (hlm.208)

Ilmu yang mengkaji tindak tutur tersebut adalah tindak tutur direktif. Menurut Yule (dalam Firdaus dkk, 2012:145-147), mendefinisikan bahwa tindak tutur direktif adalah tindak tutur yang dipakai oleh penutur untuk menyuruh orang lain melakukan sesuatu, misalnya permohonan, perintah, dan pemberian saran. Dalam tindak tutur direktif ini menginginkan petutur (lawan bicara) melakukan tindakan sebagai efek dari tuturan tersebut. Sedangkan menurut Gunarwan ( dalam Elmita dkk, 2013:140-141) tindak tutur direktif 
adalah tindak tutur yang dilakukan penuturnya dengan maksud agar si pendengar melakukan tindakan yang disebutkan di dalam tuturan itu, misalnya menyuruh, memohon, dan menantang. Selanjutnya ditegaskan pula oleh Rahardi yang menyatakan bahwa tindak tutur direktif adalah tuturan yang dimaksudkan penutur untuk membuat pengaruh agar si mitra tutur melakukan tindakan, misalnya memesan, memerintah, memohon dan menasihati.

Berkenaan dengan itu menurut Jhon Roger Searle (dalam Rustono, 1999: 38 dan Riswanti, 2014:02), ia mengemukakan bahwa tindak tutur direktif (impositif) adalah tindak tutur yang dimaksudkan penuturnya agar mitra tutur melakukan tindakan yang disebutkan dalam tuturan itu. Tuturan yang termasuk dalam tindak tutur direktif meliputi memaksa, mengajak, meminta, menyuruh, menagih, mendesak, memohon, menyarankan, memerintah, memberikan aba-aba, dan menantang. Ditambahkan lagi menurut Searle (dalam Rustono, 1999: 37 ; Riswanti, 2014 : 02), tindak tutur yang terhitung jumlahnya dan dikategorikan menjadi 5 (lima) jenis yaitu representatif, direktif, ekspresif, komisif, dan deklarasi,

Selanjutnya diperjelas lagi dengan teori Jhon Roger Searle dalam Ibrahim, (1993), ia membagi tindak tutur direktif ke dalam 6 (enam) jenis (hlm.27), yakni :
a) Permintaan (requestive),

Meliputi : meminta, memohon, menekan, mengundang, dan mendorong;

b) Pertanyaan (questions)

Meliputi: bertanya, inkuiri, dan mengintrogasi;

c) Pelarangan (prohibitives)

Meliputi : melarang dan membatasi,

d) Persyaratan(requirement)

Meliputi :

menghendaki,memerintah,mengarah kan,dan menuntut;

e) Persetujuan (permistives)
Meliputi: menyetujui, mengabulkan, mengizinkan, membolehkan, dan memaafkan;

\section{f) Nasihat (advisories)}

Meliputi:

menasihati, memperingatkan, mengusulkan, dan menyarankan

Hal senada diperkuat dengan teori dari Bach dan Harnis (dalam Syahrul, 2008:3) dan diperjelas oleh Firdaus dkk, (2012) , di mana tindak tutur direktif terbagi atas 6 (enam) kelompok jenis, (hlm.145-147), yakni :

a) Kelompok Permintaan yang mencakup meminta, memohon, mengajak, mendorong, mengundang, dan menekan;

b) Kelompok Pertanyaan, yang mencakup bertanya, berinkuiri, dan menginterogasi;

c) Kelompok Persyaratan, yang mencakup memerintah, mengomando, menuntut, mendikte, mengarahkan, menginstruksikan, mengatur, dan mensyaratkan;

d) Kelompok Larangan, yang mencakup melarang dan membatasi;

e) Kelompok Pengizinan, yang mencakup memberi izin, membolehkan, mengabulkan, melepaskan, memperkenankan, memberi wewenang, dan menganugerahi;

f) Kelompok Nasihat, yang mencakup menasihati, memperingatkan, mengusulkan, membimbing, menyarankan, dan mendorong.

\section{Fungsi Tindak Tutur Direktif}

Dalam kegiatan tindak tutur direktif, setiap tuturan yang diujarkan sekaligus memiliki fungsi komunikasinya masingmasing. Adapun fungsi tindak tutur direktif itu terdapat pada fungsi tindak tutur ilokusi. Berkenaan dengan hal ini, Leech (dalam HQ dkk, 2012 : 63-64), membagi fungsi ilokusi menjadi 4 (empat) jenis, sesuai dengan hubungan fungsi-fungsi tersebut dengan tujuan sosial berupa 
pemeliharaan perilaku yang sopan dan terhormat.

Klasifikasi fungsi ilokusi atau fungsi tuturan direktif menurut Leech adalah sebagai berikut :

(a) Kompetitif (competitive)

Tuturan dalam tindak tutur direktif fungsi kompetitif dengan tujuan sosial yang terdiri dari sub fungsi memerintah, meminta, menuntut, dan mengemis;

(b) Menyenangkan (convivia)

Tuturan dalam tindak tutur direktif fungsi convivial dengan tujuan sosial yang terdiri dari subfungsi menawarkan, mengajak atau mengundang, menyapa, mengucapkan terima kasih, dan mengucapkan selamat;

(c) Bekerja sama (collaborative)

Tuturan dalam tindak tutur direktif kolaboratif menghiraukan tujuan sosial yang terdiri dari sub fungsi menyatakan, melapor, mengumumkan, dan mengajarkan; dan

(d) Bertentangan (conflictive)

Tuturan dalam tindak tutur direktif konfliktif dengan tujuan sosial yang terdiri dari sub fungsi mengancam, menuduh, menyumpahi, dan memarahi.

Bersaman dengan teori ini menurut Searle (dalam Al-Hindawi, 2014: p. 30) distinguishes five functions of using language under which 5 (five) classes of speech acts are classified. The functions are:

a) Saying how something is;

b) Trying to get people to do something,

c) Committing ourselves to doing something;

d) Expressing sentiments or attitudes; and

e) Bringing about changes in reality

\section{METODE PENELITIAN}

Penelitian ini menggunakan metode penelitian deskriptif dan komparatif. Menurut Semi (1993) metode penelitian deskriptif adalah metode data yang diperoleh tanpa mengartikannya dengan angka-angka, tetapi menggunakan ke dalam penghayatan terhadap interaksi antar konsep yang dikaji secara empiris (hlm.23). Penelitian deskriptif hanya menggambarkan apa adanya tentang suatu variabel, gejala atau keadaan. Penelitian deskriptif bertujuan untuk membuat deskripsi, yaitu membuat gambaran, lukisan secara sistematis, faktual, dan akurat mengenai data, sifatsifat, serta hubungan fenomena yang diteliti, Djajasudarma (dalam Tussolekha dkk, 2014 : 02). Sementara itu menurut Sugiyono (2003: 11), penelitian komparatif merupakan suatu penelitian yang bersifat membandingkan. Di sini variabelnya masih sama dengan variabel mandiri tetapi untuk sample yang lebih dari satu, atau dalam waktu yang berbeda

Menurut Lofland dalam Moleong (2005) sumber data utama dalam penelitian kualitatif adalah kata-kata dan tindakan, selebihnya adalah data tambahan seperti foto dan data dari rumah sakit.

Data dalam penelitian ini yakni berbentuk teks lisan dalam tuturan direktif pada saat proses berlangsungnya kegiatan terapi pasien oleh perawat di ruang fisioterapi RS.Haji Medan - Sumatera Utara. Tuturan-tuturan tersebut dihasilkan oleh perawat dan pasien sewaktu berdialog, berinteraksi, dan berkomunikasi yang dilakukan dalam ruang fisioterapi.

Teknik pengumpulan data yang digunakan dalam penelitian ini menggunakan teknik triangulasi (gabungan). Menurut Moloeng, (2004:330), ia mengatakan bahwa triangulasi adalah teknik pemeriksaan keabsahan data yang memanfaatkan sesuatu yang lain dalam 
membandingkan hasil wawancara kegiatan pengumpulan data, penyajian terhadap objek penelitian. Teknik data, reduksi data, dan penarikan analisis data dalam penelitian ini kesimpulan yang bersifat terus-menerus menggunakan model analisis interaktif. dan saling terjalin satu dengan yang lain, Dalam model analisis interaktif ini Rusminto, (dalam Yanto dkk, 2013:02).

seluruh proses analisis data meliputi

\section{HASIL PENELITIAN DAN PEMBAHASAN}

\section{Hasil Penelitian}

Dalam kegiatan tindak tutur direktif, setiap tuturan yang diujarkan sekaligus memiliki fungsi komunikasinya masing-masing. Adapun fungsi tindak tutur direktif yang dimiliki oleh fisioterapis di ruang fisioterapi RSU. Haji Medan-Sumatera Utara dapat diuraikan seperti terlihat pada Tabel 01. :

\section{Fungsi TTD dalam Transkrip 1}

Tabel. 01. Fungsi TTD dalam TTD Permintaan dalam Transkrip 1

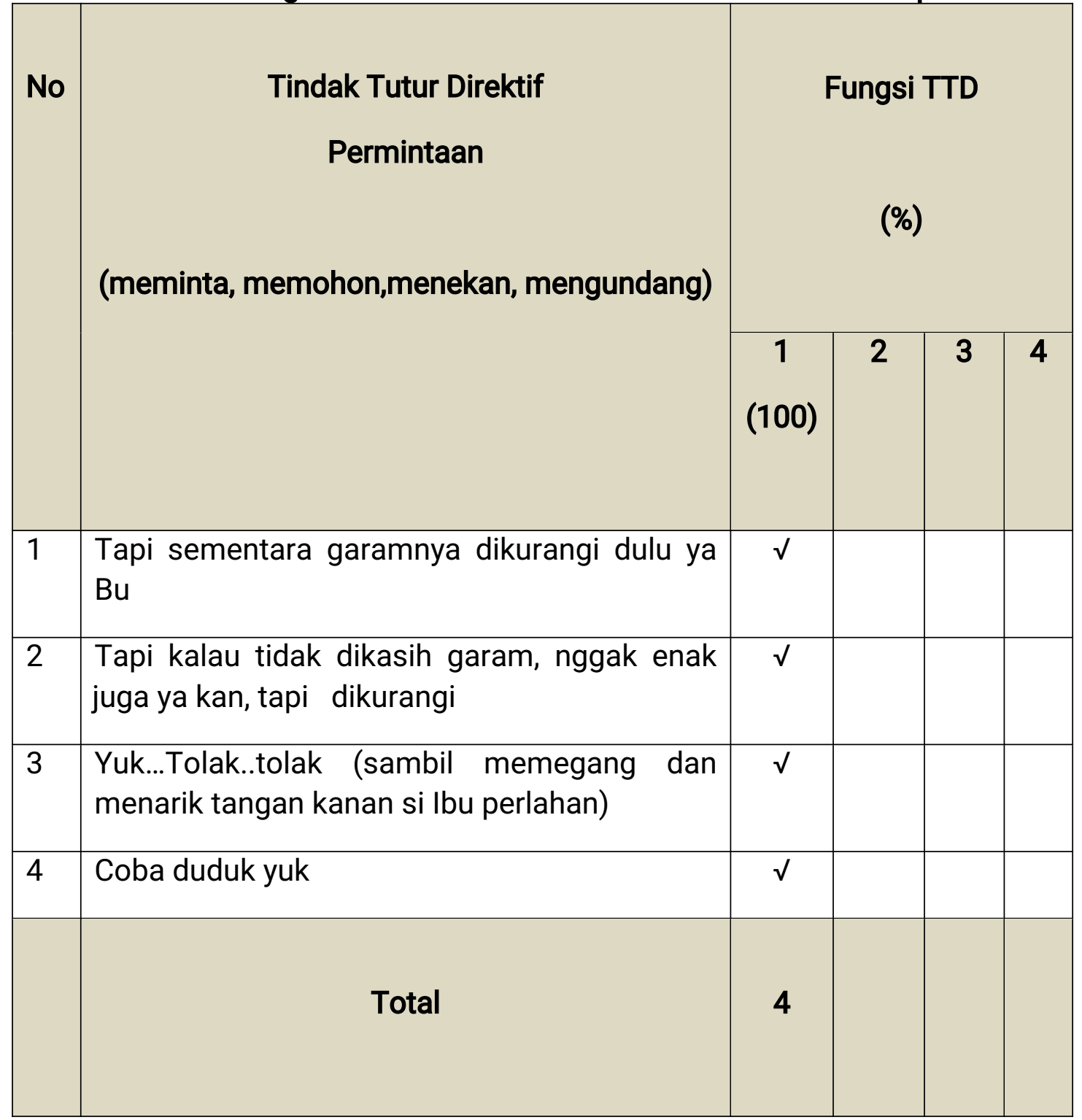


Berdasarkan Tabel 01 di atas dapat dilihat bahwa di dalam Transkrip 1 atau fisioterapis Pertama memiliki jumlah presentase fungsi Persaingan (Competitive) sebesar $100 \%$ dalam menggunakan Tindak Tutur Direktif Permintaan.

Keterangan Tabel 01. s.d. Tabel 03 :

Fungsi TTD terdiri dari :

a. Persaingan (competitive)

Memerintah, meminta, menuntut, dan mengemis

b. Menyenangkan (convivia)

Menawarkan, mengajak atau mengundang, menyapa, mengucapkan terima kasih, dan mengucapkan selamat

c. Bekerjasama (collaborative)

Menyatakan, melapor, mengumumkan, dan mengajarkan

d. Bertentangan (conflictive)

Mengancam, menuduh, menyumpahi, dan memarahi.

Tabel. 02. Fungsi TTD dalam TTD Persyaratan dalam Transkrip 1

\begin{tabular}{|c|c|c|c|c|c|}
\hline \multirow[t]{2}{*}{ No } & $\begin{array}{c}\text { Tindak Tutur Direktif } \\
\text { Persyaratan }\end{array}$ & \multicolumn{4}{|c|}{$\begin{array}{l}\text { Fungsi TTD } \\
\text { (\%) }\end{array}$} \\
\hline & $\begin{array}{c}\text { (menghendaki,memerintah,mengarahkan, } \\
\text { menuntut) }\end{array}$ & $\begin{array}{c}1 \\
(100 \\
)\end{array}$ & 2 & 3 & 4 \\
\hline 1 & Coba tutup matanya Bu & $\sqrt{ }$ & & & \\
\hline 2 & Buka & $\sqrt{ }$ & & & \\
\hline 3 & $\begin{array}{l}\text { Dorong kuat, dorong kuat, kurang, kurang } \\
\text { kuat, dorong kuat }\end{array}$ & $\sqrt{ }$ & & & \\
\hline 4 & Coba kaki kanan & $\sqrt{ }$ & & & \\
\hline 5 & Dua-dua, kaki aja dulu & $\sqrt{ }$ & & & \\
\hline 6 & $\begin{array}{l}\text { Coba bengkokkan. Angkat dulu, bengkokkan } \\
\text { lututnya, luruskan lagi, turun }\end{array}$ & $\sqrt{ }$ & & & \\
\hline 7 & $\begin{array}{l}\text { Tarik kembali kakinya } \mathrm{Bu} \text {, jempolnya angkat, } \\
\text { jempolnya aja, dua-dua... }\end{array}$ & $\sqrt{ }$ & & & \\
\hline 8 & Terus, terus, terus, tahan, tarik & $\sqrt{ }$ & & & \\
\hline 9 & Buka mulutnya, keluarkan lidahnya & $\sqrt{ }$ & & & \\
\hline
\end{tabular}




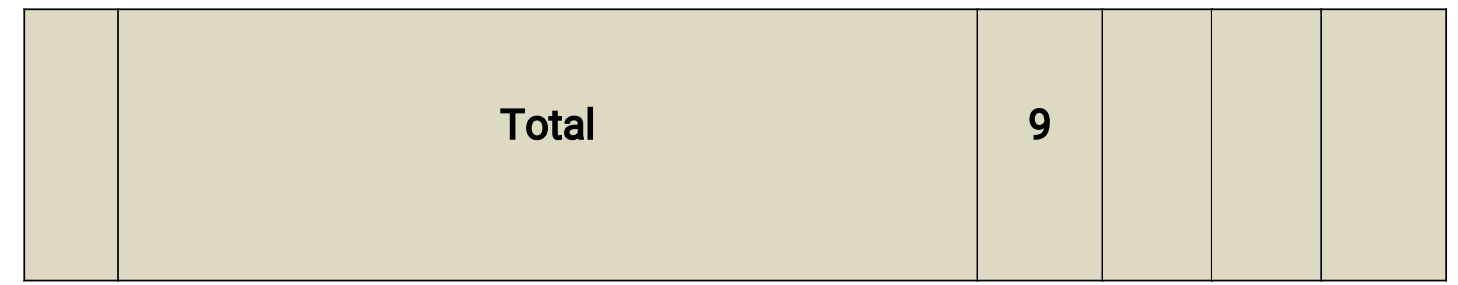

Berdasarkan Tabel.02 di atas dapat dilihat bahwa di dalam Transkrip 1 atau fisioterapis Pertama memiliki jumlah presentase fungsi Persaingan (Competitive) sebesar $\mathbf{1 0 0 \%}$ dalam menggunakan Tindak Tutur Direktif Persyaratan.

Tabel. 03. Fungsi TTD dalam TTD Nasihat dalam Transkrip 1

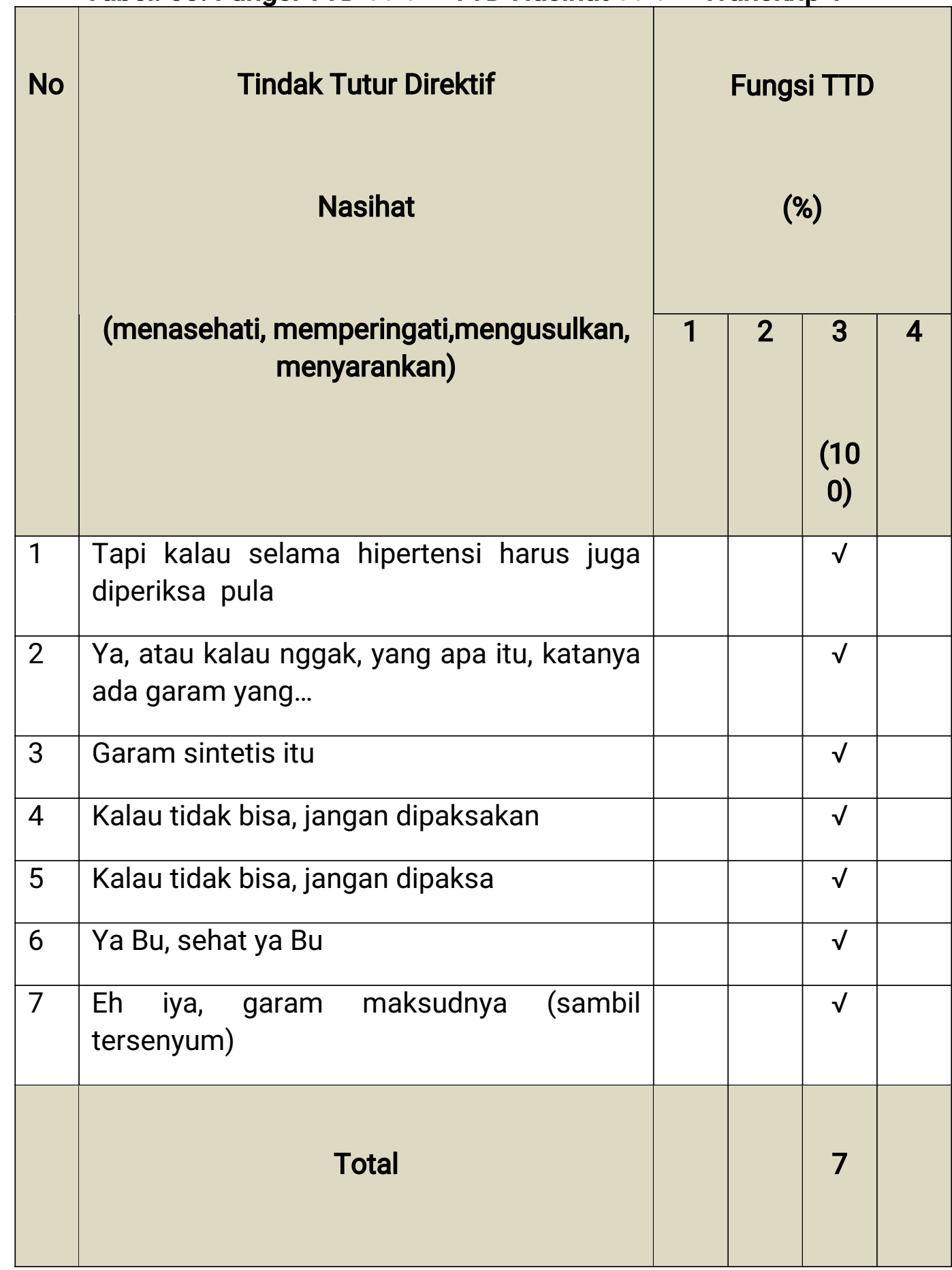


Berdasarkan Tabel. 03 di atas dapat dilihat bahwa di dalam Transkrip 1 atau fisioterapis Pertama memiliki jumlah presentase fungsi Bekerjasama (collaborative) sebesar $100 \%$ dalam menggunakan Tindak Tutur Direktif Nasihat.

II. Fungsi TTD dalam Transkrip 2

Tabel. 04. Fungsi TTD dalam TTD Permintaan dalam Transkrip 2

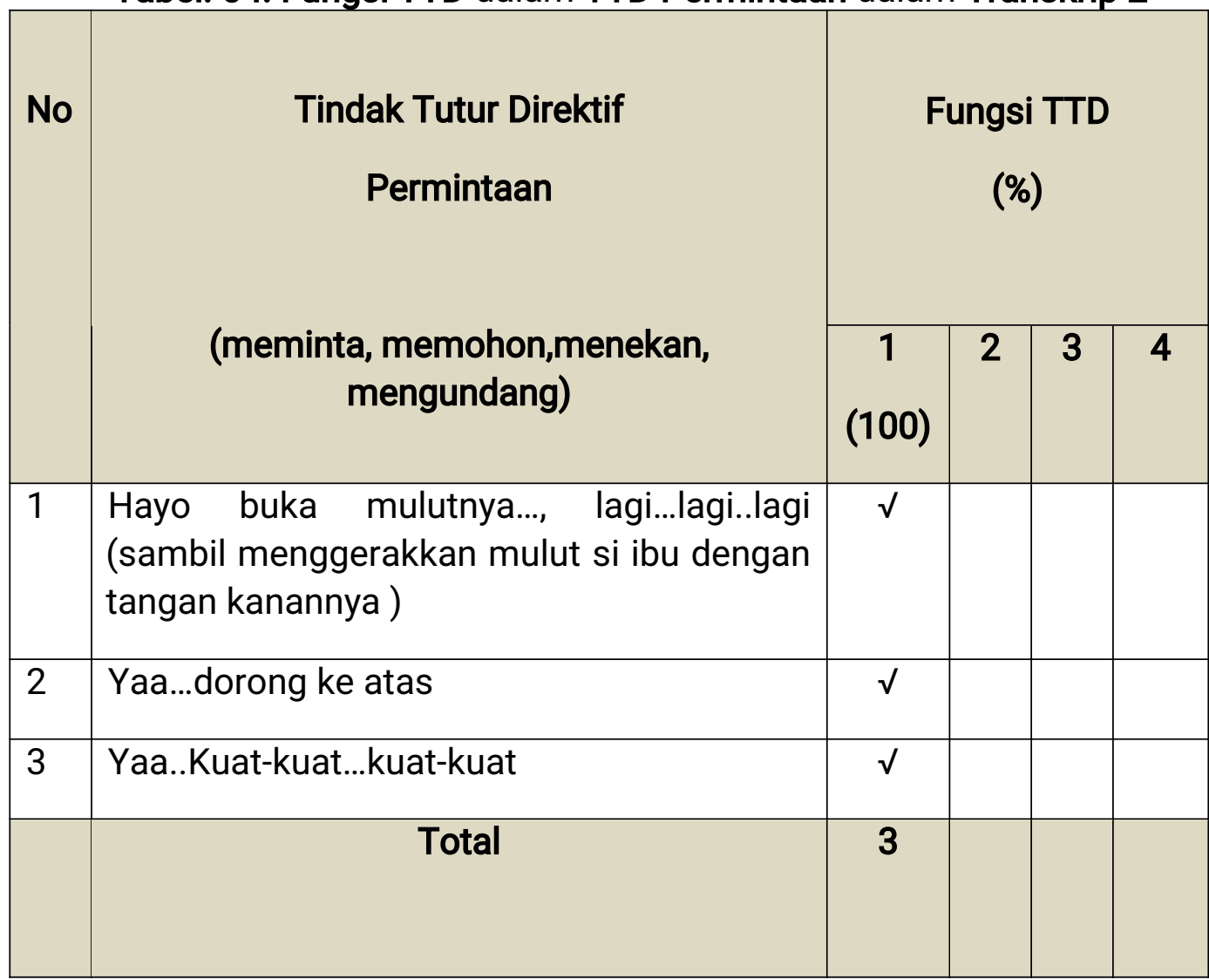

Berdasarkan Tabel. 04 dapat dilihat bahwa di dalam Transkrip 2 atau fisioterapis Kedua memiliki jumlah presentase fungsi Persaingan (competitive) sebesar $100 \%$ dalam menggunakan Tindak Tutur Direktif Permintaan.

Keterangan Tabel 04. s.d. Tabel 05 :

Fungsi TTD terdiri dari :

1. Persaingan (competitive)

Memerintah, meminta, menuntut, dan mengemis.

2. Menyenangkan (convivial)

Menawarkan, mengajak atau mengundang, menyapa, mengucapkan terima kasih, dan mengucapkan selamat;

3. Bekerja sama (collaborative)

Menyatakan, melapor, mengumumkan, dan mengajarkan;

4. Bertentangan (conflictive)

Mengancam, menuduh, menyumpahi, dan memarahi.

Tabel. 05. Fungsi TTD dalam TTD Persyaratan dalam Transkrip 2

No

Tindak Tutur Direktif

Fungsi TTD 


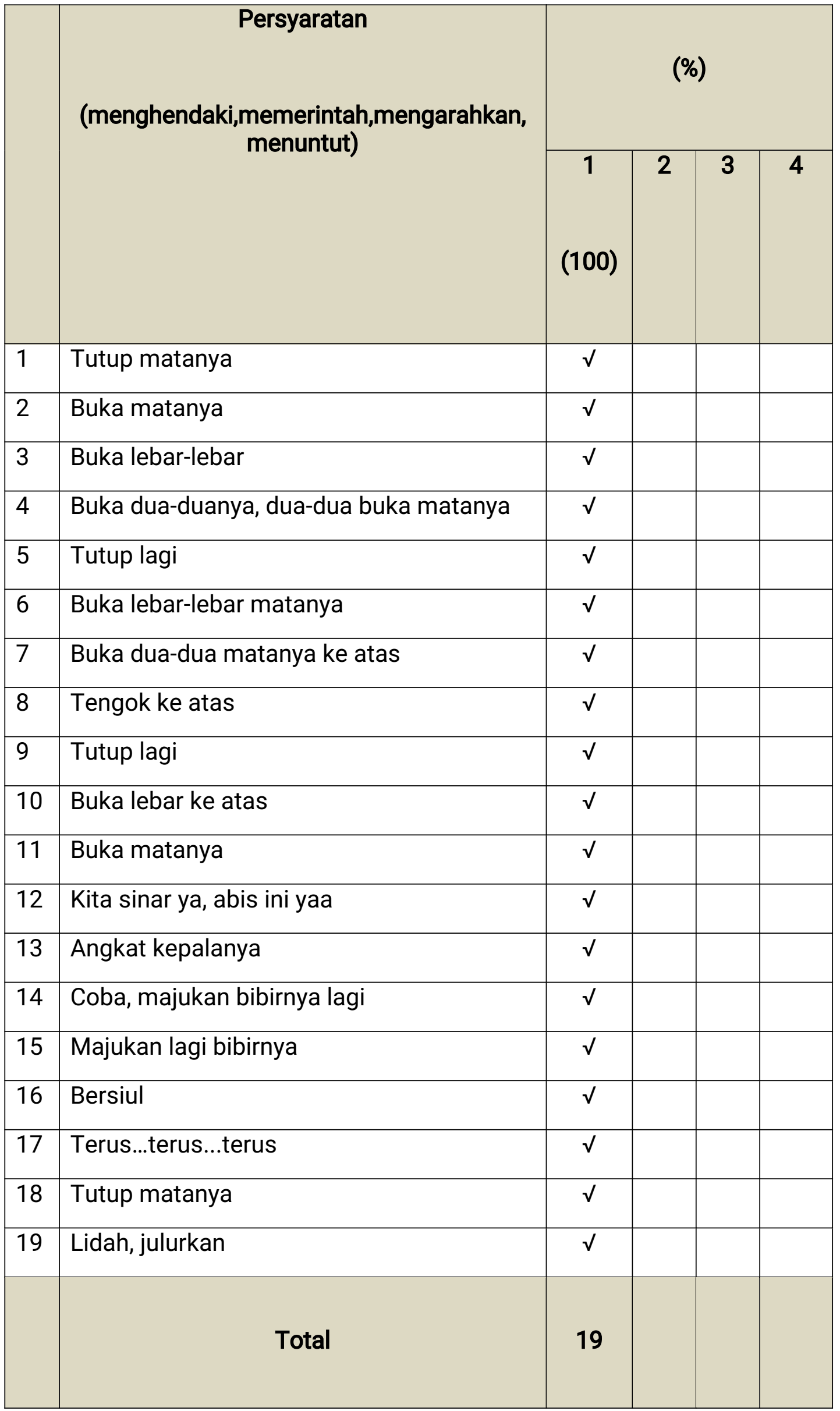


Berdasarkan Tabel. 05 di atas dapat dilihat bahwa di dalam Transkrip 1 atau fisioterapis Pertama memiliki jumlah presentase fungsi Persaingan (competitive) sebesar $100 \%$ dalam menggunakan Tindak Tutur Direktif Persyaratan.

\section{Pembahasan Hasil Penelitian}

Berdasarkan data dari hasil penelitian di atas, maka Fungsi Tindak Tutur Direktif yang digunakan oleh fisioterapis terhadap pasien di ruang fisioterapi RSU.Haji Medan-Sumatera Utara tersebut dapat dapat diuraikan sebagai berikut :

\section{Analisis Fungsi TTD Fisioterapis Pertama}

Berdasarkan hasil penelitian di lapangan dapat diperoleh data bahwa Fungsi TTD yang digunakan oleh fisioterapis Pertama adalah Fungsi TTD Persaingan (competitive), di mana ada dua indikator dari Fungsi Tuturan Direktif menurut Leech yaitu indicator meminta dan memerintah terdapat pada TTD Permintaan dan TTD Persyaratan, sedangkan Fungsi TTD Bekerjasama (collaborative) juga dimiliki oleh fisioterapis Pertama ini di mana indicator dari Fungsi TTD Bekerjasama menurut Leech yaitu indicator mengajarkan terdapat pada TTD Nasihat yakni menyarankan.

\section{Analisis Fungsi TTD Fisioterapis Kedua}

Berdasarkan hasil penelitian di lapangan dapat diperoleh data bahwa Fungsi TTD yang digunakan oleh fisioterapis Kedua adalah Fungsi TTD Persaingan (competitive), di mana ada dua indikator dari Fungsi Tuturan Direktif menurut Leech yaitu indicator meminta dan memerintah terdapat pada TTD Permintaan dan TTD Persyaratan.

Menurut Perry dan Potter
(1987), beberapa faktor yang
mempengaruhi jalannya pengiriman
dan penerimaan pesan (komunikasi)
dalam pelayanan keperawatan antara
lain:

\section{a) Persepsi}

Merupakan cara seseorang menyerap tentang sesuatu yang terjadi di sekelilingnya. Pada umumnya terkait dengan fungsi pancaindra manusia yang mencakup proses penyerapan rangsangan yang diorganisasikan dan diinterpretasikan dalam otak kemudian dijadikan persepsi. Persepsi juga merupakan kerangka tujuan yang diharapkan dan hasil setelah mengobservasi lingkungan.

\section{b) Nilai}

$$
\text { Nilai adalah keyakinan yang }
$$
dianut seseorang yang sangat dekat dengan masalah etika. Komunikasi yang terjadi antara perawat dan perawat atau kolega lainnya mungkin terfokus pada bahassan tentang upaya peningkatan dalan memberikan pertolongan tentang masalah kesehatan. Sedangkan, komunikasi dengan klien hendaknya lebih mengarah pada memberikan support dan dukungan nasehat dalam rangka mengatasi masalah klien.

\section{c) Emosi}

Emosi adalah subyektif seseorang dalam merasakan situasi yang terjadi disekelilingnya.Kekuatan emosi seorang dipengaruhi oleh bagaimana kemampuan atau kesanggupan seseorang dalam berhubungan dengan orang lain.Komunikasi akan berjalan dengan lancar dan efektif apabila perawat dapat mengelola dengan emosinya.Kemampuan profesional seseorang dapat diketahui dari emosinya dan menjadi ukuran awal seseorang dalam merasakan,bersikap dan menjalankan hubungan dengan klien.

\section{d) Latar Belakang Sosial Budaya.} Faktor ini memang sedikit 
pengaruhnya namun paling tidak dijadikan pegangan bagi perawat dalam bertutur kata,bersikap dalam berkomunikasi dalam klien.

\section{e) Pengetahuan}

Pengetahuan

merupakan

produk atau hasil dari perkembangan pendidikan. Perawat diharapkan dapat berkomunikasi dari berbagai tingkat pengetahuan yang dimiliki klien. Dengan demikian perawat dituntut mempunyai pengetahuan yang cukup tentang pertumbuhan dan perkembangan klien.

\section{f) Peran dan Hubungan}

Dalam berkomunikasi akan sangat baik bila mengenal dengan siapa dia kasi. Kemajuan hubungan perawat dan klien adalah bila hubungan tersebut saling menguntungkan dalam menjalin ide dan perasaannya. Komunikasi efektif bila partisipan mempunyai efek dan dampak positif dalam menjalin hubungan sesuai dengan perannya masing-masing.

\section{g) Kondisi Lingkungan}

Komunikasi berkaitan dengan lingkungan sosial tempat komunikasi berlangsung. Lingkungan yang kacau akan dapat merusak pesan yang dikirim oleh kedua pihak. Seorang perawat mempunyai wewenang untuk mengontrol kondisi lingkungan ketika klien datang. Perawat harus dengan tenang dan jelas dalam memberikan informasi kepada klien atau keluarganya.

\section{PENUTUP}

Fungsi tindak tutur direktif yang digunakan oleh perawat yang bertugas di ruang fisioterapi RSU. Haji Medan Sumatera Utara sudah digunakan dengan teori yang ada, yakni teori Fungsi Tindak Tutur Direktif versi Leech

\section{DAFTAR PUSTAKA}

Al-Hindawi, Fareed Hameed, etc. (2014,
March). The Speech Act Theory in English and Arabic, Open Journal of Modern Linguistics, 2014, 4, p 27-37, Published Online in SciRes

Anwari, dkk. (2013). Tindak Tutur Direktif pada Proses Pembelajaran Bahasa Indonesia di Kelas $X$. Jurnal Simbol (Bahasa, Sastra, dan Pembelajarannya). Vol. 01 No. 1. Hal 02

Elmita, Winda, dkk. (2013,Maret). Tindak Tutur Direktif Guru Dalam Proses Belajar Mengajar di TK Nusa Indah Banuaran Padang.Jurnal Pendidikan Bahasa dan Sastra Indonesia, Vol. 1 No. 2 ; Seri B 77-163,

Firdaus, Yosi Jannatul, dkk. (2012, September). Tindak Tutur Direktif Ibu Rumah Tangga Nelayan Kepada Anaknya di Kelurahan Gates Nan XX Kecamatan Lubuk Begalung Kota Padang.Jurnal Pendidikan Bahasa dan Sastra Indonesia, Vol. 1 No. 1; Seri B 87-166, hal 145-147

Hasibuan, Namsyah Hot. (2005, Oktober). Perangkat Tindak Tutur Dan Siasat Kesantunan Berbahasa (Data Bahasa Mandailing ).Jurnal Ilmiah Bahasa Dan Sastra Volume I No. 2, hal 88.

Hermawan, Andreas Hadi. (2009, November,). Persepsi Pasien Tentang Pelaksanaan Komunikasi Terapeutik Perawat dalam Asuhan Keperawatan pada Pasien di Unit Gawat Darurat RS. Mardi Rahayu Kudus, hal 02

HQ, Sherry, dkk. (2012, September).Tindak Tutur Ilokusi dalam Buku Humor "Membongkar Gurita Cikesa" Karya Jaim Wong Gendeng dan Implikasinya dalam Pembelajaran Bahasa Indonesia, Jurnal Pendidikan Bahasa dan Sastra Indonesia, Vol. 1 No. 1; Seri A 1-86, hal 63

Pratama, Purnawan Wahyu, dkk. (2013).Pendayagunaan Konteks dalam Tindak Tutur Anak Tujuh 
Tahun dan Implikasinya pada Pembelajaran, Jurnal Kata (Bahasa, Sastra, dan Pembelajarannya), Jurnal Kata (Bahasa, Sastra, dan Pembelajarannya), Vol.1 No. 7, hal 03

Raharjo,Suko.(2012,Desember).Implikt ur dalam Tindak Tutur Deklarasi : Sebuah Kajian Pragmatik terhadap Fenomena Pasuwitan pada Masyarakat Samin di Pati, Jawa Tengah, Jurnal Pengembangan Humaniora Vol. 12 No. 3, hal 206-207

Riswanti. (2014,Agustus).Analisis Tindak Tutur Direktif dan Ekspresif dalam Novel Kembang Saka Persi Karya Soebagijo I. N, Jurnal Program Studi Pendidikan Bahasa dan Sastra Jawa_Universitas Muhammadiyah Purworejo, Vol. 05 / No. 04 , hal 02

Rosnilawati, dkk. (2013,Maret). Tindak Tutur dan Strategi Bertutur dalam Pasambahan Maantaan Marapulai Pesta Perkawinan di Alahan Panjang Kabupaten Solok, Jurnal Pendidikan Bahasa dan Sastra Indonesia, Vol. 1 No. 2; Seri F 399 -476 , hal 462

Tussolekha, Rohmah, dkk.(2014
Agustus).Prinsip Kerja Sama dan Sopan Santun Siswa di Jejaring Facebook dan Implikasinya, JSimbol (Bahasa, Sastra, dan Pembelajarannya). Vol. 02 No.1, hal 01

Yuliana, Rina, dkk. (2013,April).Daya Pramagtik Tindak Tutur Guru Dalam Pembelajaran Bahasa Indonesia Pada Siswa Sekolah Menengah Pertama, BASASTRA Jurnal Penelitian Bahasa, Sastra Indonesia dan Pengajarannya, Volume 2 Nomor 1, ISSN I2302-6405, hal 04

Yanto, Jully Andry, dkk. (2013).Representasi Kekuasaan pada Tindak Tutur Guru dalam Pembelajaran Bahasa Indonesia, Jurnal-Simbol (Bahasa, Sastra, dan Pembelajarannya), Vol 1. No. 2, hal 02 